\title{
Radiological implications of Nagarparkar granite, Pakistan, as a building material
}

\author{
A.A. Qureshi ${ }^{1 \star}$, R.U.H. Siddiqui ${ }^{2}$, S. Manzoor ${ }^{1}$, A.N. Rana ${ }^{3}$ and A. Waheed ${ }^{1}$ \\ 1 Radiation Physics Laboratory, Department of Physics, COMSATS Institute of Information Technology, Park Road, Islamabad, Pakistan. \\ 2 Baluchistan University of Information Technology and Management Sciences, Quetta, Pakistan. \\ 3 Geosciences Laboratory, Chak Shahzad, Park Road, Islamabad, Pakistan.
}

Received 16 November 2015 - Accepted 29 July 2016

\begin{abstract}
The use of granite as a building material is a potential source of excessive radiation; therefore, natural radioactivity was measured in Nagarparkar granite using a HPGe $\gamma$-ray spectrometer. The average activities of ${ }^{226} \mathrm{Ra}$, ${ }^{232} \mathrm{Th}$ and ${ }^{40} \mathrm{~K}$ were found to be $25.93,41.84$ and $867.09 \mathrm{~Bq} \cdot \mathrm{kg}^{-1}$, respectively. Based on the activities of ${ }^{226} \mathrm{Ra},{ }^{232} \mathrm{Th}$ and ${ }^{40} \mathrm{~K}$, assessment of the radiation indices, annual effective dose and excess lifetime cancer risk was made. All of these were found to be comparable with the worldwide granite averages. Overall, Nagarparkar granite, Pakistan, was evaluated as a safe building material. Based on the radiation indices, annual effective dose and excess life time cancer risk, Nagarparkar granite was found to be the 7th safest building material among the world's granites. In granites of Pakistan, radioactivity increases from south to north. The granites with high radioactivity are located in the EurasianIndian Plate collision zone in Northern Pakistan.
\end{abstract}

Keywords: Granite / radioactivity / HPGe $\gamma$-ray spectrometer / excess lifetime cancer risk / plate collision

\section{Introduction}

Granites were extensively used for construction purposes in the uplands of Dartmoor National Park, the United Kingdom, and many other European countries during the Neolithic and early Bronze Age, medieval period and into modern times. Current studies show that granite dwellings may not be suitable for human habitation due to $\gamma$-radiation and the radon concentration. However, due to their durability and esthetic nature, granites are still widely used as a building material the world over.

In Pakistan, granites are found in Gilgit, Dir, Chital, Kohistan, Swat, Malakand, Swabi, Mansehra, Chagahi and Nagarparkar, where they are used as a basic construction material. In urban areas they are used as kitchen counters and vanity tops, flooring tiles, facing material for interior and exterior decoration, etc. Although it has not been specifically measured, it is generally estimated that there are more than 1000 billion tons of granite reserves in Pakistan. Mansehra and Nagarparkar granites are known to be large-scale superiorquality deposits. Apart from local use, Nagarparkar granite is exported to the Middle East and other countries.

Wynne (1867) first reported the occurrence of Nagarparkar granite, located in the extreme southeast corner of Pakistan. It

\footnotetext{
* aziz_qureshi@comsats.edu.pk
}

is located about $400 \mathrm{~km}$ to the southeast of Karachi, at $24^{\circ} 21^{\prime}$ $17^{\prime \prime} \mathrm{N}$ and $70^{\circ} 45^{\prime} 15^{\prime \prime} \mathrm{E}$ (Ali et al., 2012) (Figure 1). Kazmi and Khan (1973) assigned a Precambrian age to these rocks. Pathan and Rais (1975) proposed that these rocks are the western continuation of similar rocks exposed in the Indian Shield region, connected at depth through a batholithic mass.

Granites contain $\sim 0.5-4.7 \mathrm{ppm}$ of uranium, $\sim 1.6$ $10.7 \mathrm{ppm}$ of thorium and $\sim 37-1100 \mathrm{ppm}$ of radioactive potassium (Faure, 1986; Menegar et al., 1993). The presence of excessive activities of ${ }^{226} \mathrm{Ra},{ }^{232} \mathrm{Th}$ and ${ }^{40} \mathrm{~K}$ (primordial radionuclides) in granites are a potential source of radiation. Studies the world over have shown that the use of granites as a building material has a potential health risk. Therefore, radioactivity was measured in Nagarparkar granite using a HPGe $\gamma$-ray spectrometer to assess its suitability as a building material. The radioactivity measured in the Nagarparkar granite samples was compared with granites exposed at 50 locations in the world. Based on the limit values of various radiation indices, the annual effective dose and the excess lifetime cancer risk, the world's granites were divided into three categories for various uses. The radioactivity of Nagarparkar granite occurring in the intra-plate environment was compared with three other granites of Pakistan associated with the Eurasian-Indian Plate collision zone located in the Himalayan Ranges of Northern Pakistan. 


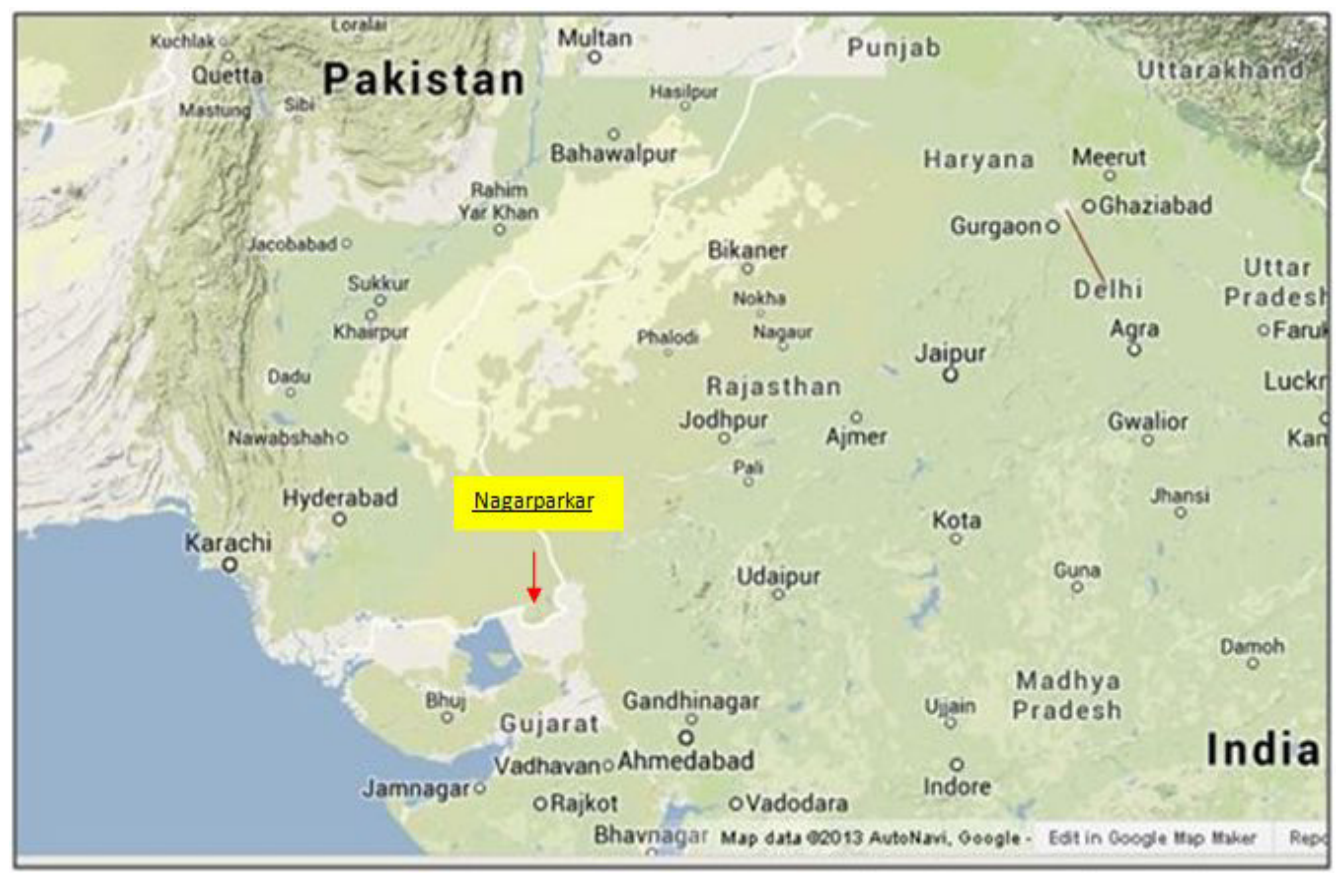

Figure 1. Location of the Nagarparkar granite in the southeast corner of Pakistan. It lies about $400 \mathrm{~km}$ to the southeast of Karachi at $24^{\circ} 21^{\prime}$ $17^{\prime \prime} \mathrm{N}$ and $70^{\circ} 45^{\prime} 15^{\prime \prime} \mathrm{E}$ (Wynne, 1867; Ali et al., 2012).

\section{Material and methods}

\subsection{Sample collection and preparation}

Twenty samples were collected from the Nagarparkar granite. The samples were crushed into small pieces, washed with water to remove the dust and sun-dried. The samples were then smashed and passed through a sieve of $200 \mu \mathrm{m}$ sized mesh to convert them into powder. The samples were then dried in an oven at $110{ }^{\circ} \mathrm{C}$ for $24 \mathrm{~h}$ (Benke and Kearfott, 1999; Yang et al., 2005) and sealed in polyethylene Marinelli beakers as per the procedure described in the literature (Le et al., 2001; Akhtar et al., 2005; Tufail et al., 2007). The net weight of each sample was noted. The reference material RG1 obtained from the Analytical Quality Control Services of the International Atomic Energy Agency was also packed in a Marinelli beaker. The samples and reference material RG1 were stored for 45 days to achieve secular equilibrium between ${ }^{226} \mathrm{Ra}$ and ${ }^{222} \mathrm{Rn}$ (Tufail et al., 2006).

\subsection{Activity measurements}

A high-purity germanium (HPGe) $\gamma$-ray spectrometer coupled with a PC-based multi-channel analyzer (MCA) along with a spectroscopy amplifier was employed for the measurement of the activity concentrations of ${ }^{226} \mathrm{Ra},{ }^{232} \mathrm{Th}$ and ${ }^{40} \mathrm{~K}$ in the samples. The detector had vertical dipstick geometry with a liquid nitrogen cooling arrangement. The diameter of the HPGe crystal was $59 \mathrm{~mm}$ and its length was $53.4 \mathrm{~mm}$. The photopeak efficiency of the detector relative to $5 \mathrm{~cm} \times$ $5 \mathrm{~cm} \mathrm{NaI}(\mathrm{Tl})$ was about $52.3 \%$ and the energy resolution was $1.85 \mathrm{keV}$ (FWHM) for the $1.33 \mathrm{MeV} \gamma$-transition of a
${ }^{60}$ Co point source. The detector was kept in a cylindrical cavity shielded with a lead and aluminum lining for protection against outer radiation (Khan et al., 1998).

The system was calibrated for energy with point sources consisting of ${ }^{241} \mathrm{Am}(59.536 \mathrm{keV}),{ }^{57} \mathrm{Co}(122.046$, $136.465 \mathrm{keV}),{ }^{137} \mathrm{Cs}(661.615 \mathrm{keV}),{ }^{60} \mathrm{Co}(1173.231,1332$ and $508 \mathrm{keV})$ and ${ }^{22} \mathrm{Na}(1274.55 \mathrm{keV})$, as described by Knoll (2000). The calibration of the detection system was accomplished using the RG1 sample containing uranium, thorium and potassium reference materials. The efficiency calibration of the system and fitting of the polynomial to the efficiency curve was described by Tufail et al. (2006).

The samples were assayed by acquiring a spectrum of each sample for $20000 \mathrm{~s}$. Background collected at the weekend was averaged and subtracted from the spectra of samples. The activity concentration of ${ }^{226} \mathrm{Ra}$ was assessed from the activities of ${ }^{214} \mathrm{~Pb}$ and ${ }^{214} \mathrm{Bi}$, whereas the ${ }^{232} \mathrm{Th}$ activity was evaluated by measuring the radioactive progeny, ${ }^{228} \mathrm{Ac},{ }^{212} \mathrm{~Pb}$ and ${ }^{208} \mathrm{Tl}$. The activity mass concentration of ${ }^{40} \mathrm{~K}$ was assessed from the $1460.8 \mathrm{keV}$ gamma transition.

The activity concentration $\boldsymbol{A}_{c t}$ of $\gamma$-rays emitted by the sample was calculated by using the following equation of Quindos et al. (1987):

$$
\boldsymbol{A}_{c t}\left(\mathrm{~Bq} \cdot \mathrm{kg}^{-1}\right)=\boldsymbol{A}-\boldsymbol{B} / \boldsymbol{\varepsilon} \boldsymbol{P} \boldsymbol{t} \boldsymbol{W}
$$

where $\boldsymbol{A}$ is the net area under the peak and $\boldsymbol{B}$ is the background area under the same peak, $\boldsymbol{P} \boldsymbol{t}$ is the emission probability of the particular $\gamma$-rays, $\boldsymbol{t}$ is the counting time, $\boldsymbol{W}$ is the weight of the sample in $\mathrm{kg}$, and $\varepsilon$ is the efficiency of the HPGe detector at the photopeak energy of the $\gamma$-ray line. 
Table 1. Gamma activity (Bq.kg ${ }^{-1}$ ) concentration of ${ }^{226} \mathrm{Ra},{ }^{232} \mathrm{Th}$ and ${ }^{40} \mathrm{~K}$, radiation indices, the annual effective dose and excessive lifetime cancer risk of Nagarparkar granite, Pakistan.

\begin{tabular}{|c|c|c|c|c|c|c|c|c|c|c|}
\hline \multirow{2}{*}{ Sample No. } & \multicolumn{4}{|c|}{ Radionuclides } & \multicolumn{4}{|c|}{ Radiation indices } & \multirow{2}{*}{$\begin{array}{c}E_{\text {in }} \\
(\mathrm{mSv})\end{array}$} & \multirow{2}{*}{$\begin{array}{l}E L C R_{\text {in }} \\
\times 10^{-3}\end{array}$} \\
\hline & $\begin{array}{c}{ }^{226} \mathbf{R a} \\
\left(\mathrm{Bq} \cdot \mathrm{kg}^{-1}\right) \\
\end{array}$ & $\begin{array}{c}{ }^{232} \mathrm{Th} \\
\left(\mathrm{Bq} \cdot \mathrm{kg}^{-1}\right) \\
\end{array}$ & $\begin{array}{c}{ }^{40} \mathrm{~K} \\
\left(\mathrm{~Bq} \cdot \mathrm{kg}^{-1}\right) \\
\end{array}$ & $\begin{array}{r}{ }^{226} \mathrm{Ra}+{ }^{232} \mathrm{Th} \\
+{ }^{40} \mathrm{~K}\left(\mathrm{~Bq} \cdot \mathrm{kg}^{-1}\right) \\
\end{array}$ & $I \gamma$ & $\begin{array}{c}R a_{e q} \\
\left(\mathrm{~Bq} \cdot \mathrm{kg}^{-1}\right) \\
\end{array}$ & $\boldsymbol{H}_{i n}$ & $\begin{array}{c}\begin{array}{c}D_{\text {in }} \\
\left(\mathrm{nGy}^{-1}\right)\end{array} \\
\end{array}$ & & \\
\hline 1 & 26.84 & 38.08 & 992.89 & 1057.81 & 0.61 & 157.62 & 0.50 & 146.01 & 0.72 & 2.51 \\
\hline 2 & 31.8 & 52.39 & 939.47 & 1023.66 & 0.68 & 178.91 & 0.57 & 162.04 & 0.80 & 2.78 \\
\hline 3 & 14.26 & 36.70 & 825.33 & 876.29 & 0.51 & 130.18 & 0.39 & 119.52 & 0.59 & 2.05 \\
\hline 4 & 29.02 & 42.21 & 812.31 & 973.22 & 0.58 & 151.81 & 0.49 & 138.11 & 0.68 & 2.37 \\
\hline 5 & 27.7 & 46.26 & 735.76 & 809.72 & 0.57 & 150.38 & 0.48 & 135.23 & 0.66 & 2.32 \\
\hline 6 & 27.95 & 41.26 & 740.71 & 809.92 & 0.55 & 143.87 & 0.46 & 130.36 & 0.64 & 2.24 \\
\hline 7 & 5.65 & 22.12 & 986.8 & 1014.57 & 0.46 & 113.16 & 0.32 & 108.47 & 0.53 & 1.86 \\
\hline 8 & 13.34 & 26.48 & 702.32 & 742.14 & 0.41 & 105.19 & 0.32 & 97.59 & 0.48 & 1.68 \\
\hline 9 & 25.15 & 38.98 & 954.21 & 1018.34 & 0.60 & 154.24 & 0.48 & 142.35 & 0.70 & 2.45 \\
\hline 10 & 29.93 & 44.87 & 1021.06 & 1095.86 & 0.66 & 172.57 & 0.55 & 158.58 & 0.78 & 2.72 \\
\hline 11 & 24.84 & 35.18 & 992.89 & 1052.91 & 0.59 & 151.47 & 0.48 & 140.98 & 0.69 & 2.42 \\
\hline 12 & 32.72 & 53.23 & 963.23 & 1049.18 & 0.70 & 182.86 & 0.58 & 165.71 & 0.81 & 2.85 \\
\hline 13 & 21.23 & 42.07 & 851.13 & 914.43 & 0.56 & 146.80 & 0.45 & 133.90 & 0.66 & 2.30 \\
\hline 14 & 32.12 & 61.07 & 731.09 & 824.28 & 0.66 & 175.60 & 0.56 & 155.21 & 0.76 & 2.67 \\
\hline 15 & 29.41 & 51.21 & 785.34 & 865.96 & 0.62 & 162.98 & 0.52 & 146.22 & 0.72 & 2.51 \\
\hline 16 & 39.15 & 49.52 & 801.17 & 889.84 & 0.65 & 171.52 & 0.57 & 154.58 & 0.76 & 2.66 \\
\hline 17 & 11.51 & 36.02 & 882.7 & 930.23 & 0.51 & 130.87 & 0.38 & 120.83 & 0.59 & 2.08 \\
\hline 18 & 31.33 & 36.71 & 799.12 & 867.16 & 0.55 & 145.24 & 0.48 & 133.13 & 0.65 & 2.29 \\
\hline 19 & 41.32 & 45.27 & 923.2 & 1009.79 & 0.67 & 177.01 & 0.59 & 161.67 & 0.79 & 2.78 \\
\hline 20 & 23.32 & 37.17 & 901.11 & 961.6 & 0.56 & 145.74 & 0.46 & 134.43 & 0.66 & 2.31 \\
\hline Minimum & 5.65 & 22.12 & 702.32 & 742.14 & 0.41 & 105.19 & 0.32 & 97.59 & 0.48 & 1.68 \\
\hline Maximum & 41.32 & 61.07 & 1021.06 & 1095.86 & 0.70 & 182.86 & 0.59 & 165.71 & 0.81 & 2.85 \\
\hline Standard Deviation & 9.03 & 9.17 & 101.52 & - & 0.07 & 21.30 & 0.08 & 18.19 & 0.09 & 0.31 \\
\hline Average & 25.93 & 41.84 & 867.09 & 939.34 & 0.58 & 152.40 & 0.48 & 139.24 & 0.68 & 2.4 \\
\hline World Wide Average & 81 & 105 & 1111 & 1297 & 1.17 & 317.66 & 1.08 & 279.64 & 1.37 & 4.8 \\
\hline Limiting Values & - & - & - & & $<1$ & 370 & $<1$ & 84 & 1 & 1.14 \\
\hline
\end{tabular}

Worldwide granite averages of $I \gamma, R a_{e q}, H_{i n}, D_{i n}, E_{i n}$ and $E L C R_{i n}$ are based on the worldwide averages of ${ }^{226} \mathrm{Ra},{ }^{232} \mathrm{Th}$ and ${ }^{40} \mathrm{~K}(81,105$ and 1111 Bq. $\mathrm{kg}^{-1}$, respectively) given in Table 2. Limit values were taken from EC, $1999(I \gamma)$; Beretka and Mathew, $1985\left(R a_{e q}\right.$ and $\left.H_{i n}\right)$; UNSCEAR, $2000\left(E_{i n}\right)$ and Nordic, $2000\left(I_{a}\right)$.

\section{Results}

\subsection{Activity concentration}

The activities of ${ }^{226} \mathrm{Ra},{ }^{232} \mathrm{Th}$ and ${ }^{40} \mathrm{~K}$ measured in the Nagarparkar granite samples are given in Table 1. The activity of ${ }^{226} \mathrm{Ra}$ varies from 5.65 to $41.32 \mathrm{~Bq} \cdot \mathrm{kg}^{-1}$, with an average value of $25.93 \mathrm{~Bq} \cdot \mathrm{kg}^{-1}$, and that of ${ }^{232} \mathrm{Th}$ from 22.12 to 61.07 Bq. $\mathrm{kg}^{-1}$, with an average value of $41.84 \mathrm{~Bq} \cdot \mathrm{kg}^{-1}$. The

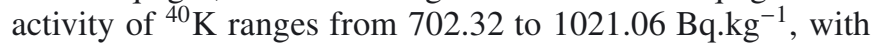
an average of $867.09 \mathrm{~Bq} \cdot \mathrm{kg}^{-1}$. The total activities due to ${ }^{226} \mathrm{Ra}$, ${ }^{232} \mathrm{Th}$ and ${ }^{40} \mathrm{~K}$ range from 742.14 to $1095.86 \mathrm{~Bq} \cdot \mathrm{kg}^{-1}$, with an average value of $939.34 \mathrm{~Bq} \cdot \mathrm{kg}^{-1} \cdot{ }^{40} \mathrm{~K}$ is the main contributor to the radioactivity $(54.48 \%)$ in Nagarparkar granite.

The activities of ${ }^{226} \mathrm{Ra},{ }^{232} \mathrm{Th}$ and ${ }^{40} \mathrm{~K}$ in granites vary over a wide range the world over (Qureshi et al., 2012). This can be seen in Table 2, which contains data from 25 countries (50 locations) and more than 1377 analyses. As Table 2 shows, a granite from Saudi Arabia has the minimum activity of ${ }^{226} \mathrm{Ra}$ : $10 \mathrm{~Bq} \cdot \mathrm{kg}^{-1}$. The Ambela granite from Pakistan contains the maximum concentration of ${ }^{226} \mathrm{Ra}: 659 \mathrm{~Bq} \cdot \mathrm{kg}^{-1}$. Two Egyptian granites from Gable el Misikat and Gable Gattar-II contain high concentrations of ${ }^{226} \mathrm{Ra}$ : 1184 and $6018 \mathrm{~Bq} \cdot \mathrm{kg}^{-1}$, respectively. These two granites may contain some radioactive mineralization and cannot be considered to be normal granites as far as building materials are concerned. The minimum concentration of ${ }^{232} \mathrm{Th}$ is found in a granite from Greece: $17 \mathrm{~Bq} \cdot \mathrm{kg}^{-1}$, whereas the maximum concentration is again found in the Ambela Granite of Pakistan: 598 Bq. $\mathrm{kg}^{-1}$. The minimum and maximum concentrations of ${ }^{40} \mathrm{~K}$ are found, respectively, in granites from Greece (104 Bq. $\mathrm{kg}^{-1}$ ) and Wadi Karim in Egypt (4849 Bq. $\mathrm{kg}^{-1}$ ). The minimum and maximum total activity is found, respectively, in granites from Greece $\left(249 \mathrm{~Bq} \cdot \mathrm{kg}^{-1}\right)$ and Wadi Karim in Egypt (4958 Bq. $\mathrm{kg}^{-1}$ ).

Due to large variations in the activities of ${ }^{226} \mathrm{Ra},{ }^{232} \mathrm{Th}$ and ${ }^{40} \mathrm{~K}$ in granites, it is difficult to estimate an average concentration of these radionuclides the world over. Based on the data in Table 2, average values of ${ }^{226} \mathrm{Ra},{ }^{232} \mathrm{Th}$ and ${ }^{40} \mathrm{~K}$ were estimated to be 111,127 and $1309 \mathrm{~Bq} \cdot \mathrm{kg}^{-1}$, respectively, during the present study. The average values of ${ }^{226} \mathrm{Ra},{ }^{232} \mathrm{Th}$ and ${ }^{40} \mathrm{~K}$ 
Table 2. Comparison of gamma activity (Bq. $\mathrm{kg}^{-1}$ ) of ${ }^{226} \mathrm{Ra},{ }^{232} \mathrm{Th}$ and ${ }^{40} \mathrm{~K}$ and their total in Nagarparkar granite, Pakistan, with some of the world's other granites.

\begin{tabular}{|c|c|c|c|c|c|c|c|}
\hline No. & Country/location & Samples & ${ }^{226} \mathbf{R a}$ & ${ }^{232} \mathrm{Th}$ & ${ }^{40} \mathrm{~K}$ & Total & Reference \\
\hline 1 & Pakistan (Nagarparkar granite) & 20 & 26 & 42 & 867 & 939 & Present study \\
\hline 2 & Pakistan (Mansehra granite) & 30 & 27 & 50 & 953 & 1030 & Qureshi et al. (2014) \\
\hline 3 & Pakistan (S. S. Garhi granite) & 42 & 51 & 70 & 1853 & 1974 & Amanat et al. (2002) \\
\hline 4 & Pakistan (Ambela granite) & 20 & 659 & 598 & 1203 & 2460 & Asghar et al. (2008) \\
\hline 5 & Africa & 4 & 23 & 42 & 811 & 876 & Tzortzis et al. (2003) \\
\hline 6 & Austria & 1 & 40 & 253 & 1340 & 1633 & Chen and Lin (1996) \\
\hline 7 & Belgium & 1 & 68 & 77 & 1129 & 1274 & Tzortzis et al. (2003) \\
\hline 8 & Brazil & 1 & 91 & 152 & 1819 & 2062 & Chen and Lin (1996) \\
\hline 9 & Brazil & 14 & 82 & 168 & 1297 & 1547 & Tzortzis et al. (2003) \\
\hline 10 & Brazil & 71 & 45 & 106 & 1320 & 1471 & Anjos et al. (2011) \\
\hline 11 & Brazil & 95 & 31 & 73 & 1648 & 1752 & Anjos et al. (2005) \\
\hline 12 & China & $10(\gamma)$ & 88 & 114 & 1270 & 1472 & Xinwei et al. (2006) \\
\hline 13 & China & 3 & 23 & 36 & 891 & 950 & Xinwei et al. (2008) \\
\hline 14 & China & 8 & 95 & 158 & 1256 & 1509 & Chen and Lin (1996) \\
\hline 15 & China & 55 & 112 & 71 & 672 & 839 & Yang et al. (2005) \\
\hline 16 & Cypress & 28 & 74 & 140 & 1076 & 1290 & Tzortzis et al. (2003) \\
\hline 17 & Egypt Wadi Karim & 39 & 56 & 54 & 4849 & 4958 & El-Arabi (2007) \\
\hline 18 & Egypt/Gable El Aradiya & 10 & 126 & 25 & 480 & 631 & Arafa (2004) \\
\hline 19 & Egypt/Gable El Majal & 10 & 198 & 30 & 681 & 909 & Arafa (2004) \\
\hline 20 & Egypt/HomertWaggat North & 10 & 489 & 109 & 1590 & 2188 & Arafa (2004) \\
\hline 21 & Egypt/HomertWaggat South & 10 & 87 & 162 & 2301 & 2650 & Arafa (2004) \\
\hline 22 & Egypt/Um Taghir & 39 & 558 & 359 & 3918 & 4835 & El-Arabi (2007) \\
\hline 23 & Egypt/Gable El Misikat-1 & 9 & 1184 & 40 & 705 & 1929 & Arafa (2004) \\
\hline 24 & Egypt Gable Gattar II & 10 & 6018 & 113 & 1140 & 7271 & El- Shershaby (2002) \\
\hline 25 & Europe South Eastern & 13 & 42 & 42 & 630 & 714 & Krstić et al. (2007) \\
\hline 26 & Finland & 3 & 94 & 163 & 1223 & 1483 & Chen and Lin (1996) \\
\hline 27 & Ghana/Kasoa & 11 & 76 & 48 & 731 & 855 & Otoo et al. (2011) \\
\hline 28 & Greece & 26 & 18 & 17 & 367 & 402 & Stoulos et al. (2003) \\
\hline 29 & Greece & 16 & 64 & 81 & 104 & 249 & Pavlidou et al. (2006) \\
\hline 30 & India & 4 & 119 & 172 & 1082 & 1373 & Chen and Lin (1996) \\
\hline 31 & India & 4 & 93 & 306 & 1074 & 1473 & Sannappa et al. (2010) \\
\hline 32 & Iran & 14 & 130 & 83 & 1287 & 1500 & Jahangiri and Ashrafi (2011) \\
\hline 33 & Italy & 4 & 162 & 490 & 1540 & 2192 & Tzortzis et al. (2003) \\
\hline 34 & Italy & 4 & 64 & 91 & 1206 & 1361 & Menager et al. (1993) \\
\hline 35 & Malaysia & 1 & 86 & 134 & 1019 & 1239 & Chen and Lin (1996) \\
\hline 36 & Palestine & 40 & 71 & 82 & 781 & 934 & Khaleel (2013) \\
\hline 37 & Portugal & 1 & 117 & 105 & 1490 & 1712 & Chen and Lin (1996) \\
\hline 38 & Saudi Arabia & 45 & 31 & 27 & 534 & 592 & Alharbi et al. (2012) \\
\hline 39 & Saudi Arabia & 1 & 10 & 29 & 664 & 703 & Qureshi et al. (2012) \\
\hline 40 & South Africa & 1 & 92 & 153 & 1151 & 1396 & Chen and Lin (1996) \\
\hline 41 & Spain & 1 & 80 & 123 & 1289 & 1492 & Chen and Lin (1996) \\
\hline 42 & Spain & 41 & 84 & 42 & 1414 & 1588 & Guillén et al. (2014) \\
\hline 43 & Sweden & 2 & 107 & 110 & 1226 & 1443 & Chen and Lin (1996) \\
\hline 44 & Turkey & 41 & 88 & 95 & 1055 & 1238 & Turhan (2012) \\
\hline 45 & Turkey (Ezine) & $10(\gamma)$ & 175 & 205 & 1172 & 1552 & Orgun et al. (2005) \\
\hline 46 & Turkey/Kaymaz & 7 & 306 & 248 & 1266 & 1820 & Orgun et al. (2005) \\
\hline 47 & Turkey/Sivrihisar & 7 & 67 & 153 & 1058 & 1278 & Orgun et al. (2005). \\
\hline 48 & European Union (Database) & 387 & 78 & 89 & 1049 & 1116 & Trevisi et al. (2012) \\
\hline 49 & USA & $10(\gamma)$ & 57 & 69 & 1140 & 1266 & Kitto et al. (2009) \\
\hline 50 & Yemen & 3 & 54 & 127 & 1743 & 1623 & Abd El-Mageed et al. (2011) \\
\hline \multicolumn{2}{|c|}{ a. Average based on above data } & 1377 & 111 & 127 & 1309 & 1551 & Qureshi (current study) \\
\hline \multicolumn{2}{|c|}{ b. World granite Average } & 137 & 42 & 73 & 1055 & 1170 & Chen and Lin (1996) \\
\hline \multicolumn{2}{|c|}{ c. China granite Average } & - & 90 & 116 & 969 & 1175 & Mao et al. (2006) \\
\hline \multicolumn{2}{|c|}{ Worldwide Average $(\mathrm{a}+\mathrm{b}+\mathrm{c})$} & & 81 & 105 & 1111 & 1299 & \\
\hline
\end{tabular}

Analyses 23 and 24 not included in the average calculation. 
in 137 granites were reported by Chen and Lin (1996) to be 42, 73 and $1055 \mathrm{~Bq} \cdot \mathrm{kg}^{-1}$, respectively. Mao et al. (2006) reported average values of 90,116 and $969 \mathrm{~Bq} \cdot \mathrm{kg}^{-1}$ in China's granites. By combining the average data of the present study, with those of Chen and Lin (1996) and Mao et al. (2006), the average values of ${ }^{226} \mathrm{Ra},{ }^{232} \mathrm{Th}$ and ${ }^{40} \mathrm{~K}$ were estimated to be 81,105 and $1111 \mathrm{~Bq} \cdot \mathrm{kg}^{-1}$, which are considered standard worldwide averages in the present study.

The average activities of ${ }^{226} \mathrm{Ra},{ }^{232} \mathrm{Th}$ and ${ }^{40} \mathrm{~K}$ in the Nagarparkar granite samples are 0.32, 0.39 and 0.79 times lower than the worldwide average activity levels $(81,105$ and 1111 Bq. $\mathrm{kg}^{-1}$ ) of granites.

Four granites from Pakistan, including the current study, have been investigated using spectrometric techniques. From south to north, they are located in Nagarparkar, Mansehra, Shewa Shahbaz Garhi and Ambela. The radioactivity of ${ }^{226} \mathrm{Ra}$, ${ }^{232} \mathrm{Th}$ and ${ }^{40} \mathrm{~K}$ in these granites increases from south to north. The Nagarparkar granite exposed in the southern part of Pakistan has the lowest activity concentrations of ${ }^{226} \mathrm{Ra},{ }^{232} \mathrm{Th}$ and ${ }^{40} \mathrm{~K}$ : 25.93 (26), 41.84 (42) and 867.09 (867) Bq.kg ${ }^{-1}$, respectively. The Mansehra granite exposed about $1146 \mathrm{~km}$ north of Nagarparkar granite has slightly higher activity concentrations of ${ }^{226} \mathrm{Ra},{ }^{232} \mathrm{Th}$ and ${ }^{40} \mathrm{~K}: 27,50$ and $953 \mathrm{~Bq} \cdot \mathrm{kg}^{-1}$, respectively. The Shewa Shabaz Garhi granite exposed 1234 $\mathrm{km}$ north of Nagarparkar granite has higher activity concentrations of ${ }^{226} \mathrm{Ra},{ }^{232} \mathrm{Th}$ and ${ }^{40} \mathrm{~K}: 51,70$ and $1853 \mathrm{~Bq} \cdot \mathrm{kg}^{-1}$, respectively. The Ambela granite, which is located $1295 \mathrm{~km}$ north of Nagarparkar, has the significantly highest ${ }^{226} \mathrm{Ra},{ }^{232} \mathrm{Th}$ and ${ }^{40} \mathrm{~K}$ activity levels of 659,598 and $1203 \mathrm{~Bq} \cdot \mathrm{kg}^{-1}$, respectively. The systematic increase in the radioactivity in the four granites can be seen in Table 2 and Figure 2. This increase is attributed to their association with the Eurasian-Indian Plate collision zone in the Himalayas of Northern Pakistan. Nagarparkar Granite is exposed in the intra-plate zone within the Indian Plate.

\subsection{Radiation hazard indices}

Radiation indices, namely the gamma index $(I \gamma)$, radium equivalent activity $\left(R a_{e q}\right)$, internal hazard index $\left(H_{\text {in }}\right)$ and indoor external dose $\left(D_{i n}\right)$, were estimated on the basis of the activities of ${ }^{226} \mathrm{Ra},{ }^{232} \mathrm{Th}$ and ${ }^{40} \mathrm{~K}$ in the Nagarparkar granite samples to assess it as a building material. The formulae used for the assessment of the radiation indices are given in Appendix. The averages of the various indices for the granites were calculated on the basis of the worldwide average activities of ${ }^{226} \mathrm{Ra}$, ${ }^{232} \mathrm{Th}$ and ${ }^{40} \mathrm{~K}\left(81,105\right.$ and $\left.1111 \mathrm{~Bq} \cdot \mathrm{kg}^{-1}\right)$ reported in Table 2.

\subsubsection{Gamma index I $\gamma$}

Materials that have $I \gamma \leq 1$ means an annual effective dose of $0.3 \mathrm{mSv}$, while $I \gamma \geq 1 \leq 6$ corresponds to an annual effective dose of $1 \mathrm{mSv} \cdot \mathrm{y}^{-1}$ (Chen and Lin, 1996; EC, 1999).

The average calculated value of $I \gamma$ for Nagarparkar granite is 0.58 , which is less than the worldwide average of 1.17 and the criterion limit of unity. Details concerning the calculated values of various radiation indices during the present study are given in Table 1.

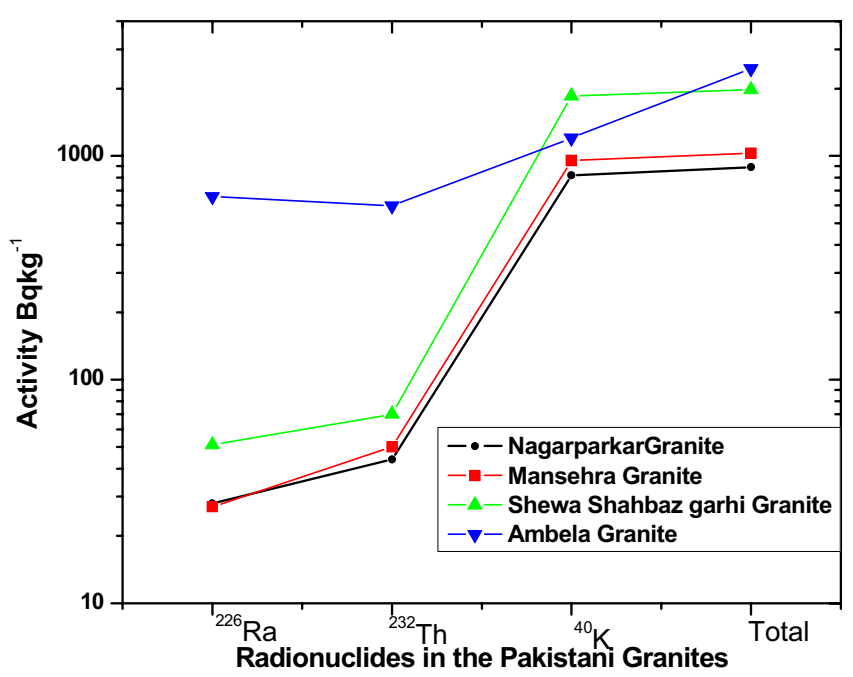

Figure 2. Data from four Pakistani granites show that radioactivity increases from south to north. The lowest values of ${ }^{226} \mathrm{Ra},{ }^{232} \mathrm{Th}$, ${ }^{40} \mathrm{~K}$ and total activity are found in the Nagarparkar granite (current study) exposed in the southernmost part of Pakistan. Slightly higher values are found in the Mansehra Granite, which is located about $1147 \mathrm{~km}$ north of the Nagarparkar granite. Significantly higher values were noted in the Shewa Shabaz Garhi granite, $1234 \mathrm{~km}$ north of the Nagarparkar granite, and Ambela granite, $1295 \mathrm{~km}$ north of the Nagarparkar granite.

\subsubsection{Radium equivalent activity $R a_{e q}$}

In order to assess the total impact of radioactivity due to ${ }^{226} \mathrm{Ra},{ }^{232} \mathrm{Th}$ and ${ }^{40} \mathrm{~K}$ present in any material, a common radiological index known as radium equivalent activity $R a_{e q}$ was calculated.

The limit value of $R a_{e q}$ is $370 \mathrm{~Bq} \cdot \mathrm{kg}^{-1}$, which corresponds to an annual effective dose of $1.5 \mathrm{mSv}$ and the hazard index $\left(H_{i n}\right)$ of unity. The average value of $R a_{e q}$ of the Nagarparkar granite samples is $152.40 \mathrm{~Bq} \cdot \mathrm{kg}^{-1}$, which is far below the worldwide average of $317.69 \mathrm{~Bq} \cdot \mathrm{kg}^{-1}$ and the criterion limit of $370 \mathrm{~Bq} \cdot \mathrm{kg}^{-1}$ for granites.

\subsubsection{Internal hazard index $H_{\text {in }}$}

For any material to qualify as a radiation-safe building material, the $H_{\text {in }}$ should be less than unity (Krisiuk et al., 1971; Krieger, 1981; Beretka and Matthew, 1985). The granite under study has an average $H_{\text {in }}$ value of 0.48 , which is well below the worldwide granite average of 1.08 and the criterion limit of unity.

\subsubsection{Indoor external dose $D_{\text {in }}$}

For the selection of a safe building material, an index called the indoor external dose rate $D_{i n}$ is calculated for a standard room with dimensions of $4 \mathrm{~m} \times 5 \mathrm{~m} \times 2.8 \mathrm{~m}$, with wall thickness of $20 \mathrm{~cm}$.

The average value of $D_{\text {in }}$ calculated for Nagarparkar granite is $139.24 \mathrm{nGy} \cdot \mathrm{h}^{-1}$, which is lower than the worldwide average of $279.64 \mathrm{nGy} \cdot \mathrm{h}^{-1}$ but 1.7 times higher than the limit value 
of 84 nGy.h ${ }^{-1}$ (UNSCEAR, 2000). The $D_{\text {in }}$ calculated in most studies in the world is usually found to be higher than the limit value of $84 \mathrm{nGy} \cdot \mathrm{h}^{-1}$, as the formula used for the calculation of $D_{i n}$ is for a room with closed dimensions of $4 \mathrm{~m} \times 5 \mathrm{~m} \times 2.8 \mathrm{~m}$, with wall thickness of $20 \mathrm{~cm}$. However, all buildings may not have the same dimensions. As far as this criterion is concerned, the Nagarparkar granite contains a slightly higher concentration of radioactivity but may be used as a construction material. The buildings constructed using Nagarparkar granite should have sufficient apertures and ventilation options.

\subsection{Annual effective dose $E_{\text {in }}$}

The annual effective dose $D_{\text {in }}$ due to the measured activities of ${ }^{226} \mathrm{Ra},{ }^{232} \mathrm{Th}$ and ${ }^{40} \mathrm{~K}$ in the granite samples was converted into $E_{\text {in }}$ in air one meter above the ground surface using the conversion factor $\left(0.7 \mathrm{~Sv} \cdot \mathrm{Gy}^{-1}\right)$ and indoor occupancy factor (0.8).

The $E_{\text {in }}$ calculated during the present investigation for Nagarparkar granite ranges from 0.48 to 0.81 , with an average value of $0.68 \mathrm{mSv}^{-1} \mathrm{y}^{-1}$. As per the UNSCEAR (2000) report, the average value of $E_{i n}$ for an adult person is $0.3 \mathrm{mSv}_{\text {. }} \mathrm{y}^{-1}$. The average value of $E_{\text {in }}$ calculated during the present study is below the worldwide granite average of $1.37 \mathrm{mSv} \cdot \mathrm{y}^{-1}$ and the limit value of $1 \mathrm{mSv} \cdot \mathrm{y}^{-1}$ as per the UNSCEAR (2000) report.

\subsection{Excess lifetime cancer risk $E \boldsymbol{L C} \boldsymbol{R}_{\text {in }}$}

According to the Surveillance, Epidemiology and End Results Cancer Statistics Review, American men have a $44 \%$ lifetime cancer risk, while women have a $38 \%$ lifetime cancer risk due to background radiation exposure (National Cancer Institute, 2009). This means that there is a chance that a person will get some type of cancer at some stage of life due to background radioactivity and inheritance factors. The excess lifetime cancer risk is the additional risk that someone might have of getting cancer if that person is exposed to excessive radiation or other cancer-causing materials for a longer time. A major source of excessive radiation for an ordinary person is from the indoor environment, so the $E L C R_{\text {in }}$ is calculated from the indoor annual effective dose that a person receives from his indoor environment, where he spends $80 \%$ of his life-time.

Based upon the values of $\left(E_{i n}\right)$ calculated during the present study, the $E L C R_{\text {in }}$ due to the indoor exposure from Nagarparkar granite was estimated using the equation given in Appendix. In the equation, $E_{\text {in }}$ is the indoor annual effective dose, $L E$ the life expectancy (66 years for Pakistan) and $R F$ is the fatal risk factor per Sievert, which is 0.05 as per ICRP Publication 65 (1994).

The $E L C R_{\text {in }}$ calculated during the present study, given in Table 1 , has an average value of $2.4 \times 10^{-3}$, which is lower than the worldwide average of $4.8 \times 10^{-3}$. However, it is higher than the limit of $1.16 \times 10^{-3}$ set for the possibility of having cancer due to normal radioactivity in the indoor environment. As far as this criterion is concerned, the Nagarparkar granite has a 1.93 times higher risk of inducing cancer for a person living for 66 years in a dwelling made of Nagarparkar granite.

\section{Discussion}

Based on the activities of ${ }^{226} \mathrm{Ra},{ }^{232} \mathrm{Th}$ and ${ }^{40} \mathrm{~K}$ in Nagarparkar granite, assessment of the radiation indices, annual effective dose and excess lifetime cancer risk was made. Three radiation indices, $\left.(I \gamma=0.58), R a_{e q}=152.40\right)$ and $\left(H_{\text {in }}=0.48\right)$, are lower than the worldwide averages for granites $(1.17,317.66$ and 1.08$)$ and their limit values $(<1,370$ and $<1)$. The indoor external dose $\left(D_{i n}=139.24\right)$ is lower than the worldwide average of 279.64, but higher than its limit value of 84 , which is usually the case for most granites in the world.

The indoor annual effective dose $\left(E_{\text {in }}=0.68\right)$ is lower than the worldwide average of 1.37 and its limit value of unity. The excess lifetime cancer risk $E L C R_{\text {in }}$ of Nagarparkar granite is $2.4 \times 10^{-3}$, which is less than the worldwide average of $4.8 \times 10^{-3}$ but higher than the limit value of $1.14 \times 10^{-3}$. As per the limit value, Nagarparkar granite imposes a $1.93 \%$ higher chance of inducing cancer as compared with a building material with normal radioactivity. This can be considered within the safe limits, as other granites have very high values of the $E L C R_{\text {in }}$.

Overall, Nagarparkar granite was evaluated as a suitable building material that can be used as a basic construction material with the provision of proper ventilation in the building design, and for decorative uses without any restriction.

Most of the worlds' needs are fulfilled from the granites listed in Table 3. Radiation indices, the annual effective dose and the excess lifetime cancer risk were calculated for these granites on the basis of their activity concentrations of ${ }^{226} \mathrm{Ra}$, ${ }^{232} \mathrm{Th}$ and ${ }^{40} \mathrm{~K}$. Table 3 shows that there is no linear relationship between the activity concentrations of ${ }^{226} \mathrm{Ra},{ }^{232} \mathrm{Th}$ and ${ }^{40} \mathrm{~K}$ and the radiation indices, annual dose and excess lifetime cancer risk. This is because the $\gamma$-activity of ${ }^{232}$ Th imparts 1.42 and 18.57 times more $\gamma$-ray dose equivalent than the activity concentrations of ${ }^{226} \mathrm{Ra}$ and ${ }^{40} \mathrm{~K}$, respectively. Therefore, the $\gamma$ activity of ${ }^{232} \mathrm{Th}$ substantially increases the magnitude of various radiation indices, the annual effective dose and the excess lifetime cancer risk.

As per Table 3, some granites fit one criterion and are not suitable according to another criterion as a basic construction material or for restricted use. As per the limit values of $(I \gamma=1),\left(R a_{e q}=370 \mathrm{~Bq} \cdot \mathrm{kg}^{-1}\right),\left(H_{\text {in }}=1\right)$ and $\left(E_{\text {in }}=1\right.$ $\left.\mathrm{mSv} . \mathrm{y}^{-1}\right)$; only $32 \%, 62 \%, 40 \%$ and $26 \%$ of the world's granites, listed in Table 3, qualify as radiation-safe material for basic construction. An approximate division of granites for various uses as discussed above is given in Table 3.

In four granites from Pakistan investigated using the $\gamma$ spectrometric technique, radioactivity increases from south to north. The Nagarparkar granite exposed in the southernmost part of Pakistan has the lowest activities of ${ }^{226} \mathrm{Ra},{ }^{232} \mathrm{Th}$ and ${ }^{40} \mathrm{~K}$. The Mansehra granite, Shewa Shabaz Garhi granite and Ambela granite located more than $1000 \mathrm{~km}$ north of Nagarparkar have higher activities of ${ }^{226} \mathrm{Ra},{ }^{232} \mathrm{Th}$ and ${ }^{40} \mathrm{~K}$ : these three granites are located within the Eurasian-Indian Plate collision zone. The Nagarparkar Granite, with the lowest activities of ${ }^{226} \mathrm{Ra},{ }^{232} \mathrm{Th}$ and ${ }^{40} \mathrm{~K}$, is in the intra-plate environment within the Indian Plate. 
Table 3. Comparison of gamma activity $\left(\mathrm{Bq} \cdot \mathrm{kg}^{-1}\right)$ and the radiation indices, annual effective dose and excess lifetime cancer risk of Nagarparkar granite, Pakistan, with granites in some other countries is shown in ascending order. Based on various indices, the granites have been classified into three categories.

\begin{tabular}{|c|c|c|c|c|c|c|c|c|}
\hline No. & Country & $I \gamma$ & $\begin{array}{c}R a_{e q} \\
\left(\mathrm{~Bq} \cdot \mathrm{kg}^{-1}\right)\end{array}$ & $H_{\text {in }}$ & $\begin{array}{c}D_{\text {in }} \\
\left(\mathrm{nGy} \cdot \mathrm{h}^{-1}\right)\end{array}$ & $\begin{array}{c}E_{\text {in }} \\
(\mathrm{mSv})\end{array}$ & $\begin{array}{l}E L C R_{\text {in }} \\
\times 10^{-3} \\
\end{array}$ & Category \\
\hline 1 & Greece & 0.27 & 70.52 & 0.24 & 64.62 & 0.32 & 1.11 & $\begin{array}{l}\text { May be used as a construction } \\
\text { material without any restriction }\end{array}$ \\
\hline 2 & Saudi Arabia & 0.40 & 102.51 & 0.30 & 94.22 & 0.46 & 1.62 & \\
\hline 3 & Saudi Arabia & 0.42 & 110.65 & 0.38 & 100.94 & 0.50 & 1.73 & \\
\hline 4 & Africa & 0.56 & 145.38 & 0.46 & 132.24 & 0.65 & 2.27 & \\
\hline 5 & China & 0.55 & 142.97 & 0.45 & 132.04 & 0.65 & 2.27 & \\
\hline 6 & Europe South Eastern & 0.56 & 150.46 & 0.52 & 135.24 & 0.66 & 2.32 & \\
\hline 7 & Pakistan (Nagarparkar Granite) & 0.58 & 152.4 & 0.45 & 139.24 & 0.68 & 2.40 & \\
\hline 8 & Pakistan (Mansehra Granite) & 0.66 & 171.74 & 0.54 & 156.08 & 0.77 & 2.68 & \\
\hline 9 & Greece & 0.65 & 187.71 & 0.68 & 156.30 & 0.77 & 2.68 & \\
\hline 10 & Egypt/Gable El Aradiya & 0.71 & 198.64 & 0.88 & 181.82 & 0.89 & 3.12 & \\
\hline 11 & Ghana/Kasoa & 0.74 & 200.80 & 0.75 & 181.20 & 0.89 & 3.11 & \\
\hline 12 & Palestine & 0.91 & 248.22 & 0.86 & 218.00 & 1.07 & 3.74 & \\
\hline 13 & USA & 0.92 & 243.26 & 0.81 & 219.54 & 1.08 & 3.77 & \\
\hline 14 & China & 0.95 & 265.12 & 1.02 & 234.90 & 1.15 & 4.04 & \\
\hline 15 & Spain & 0.96 & 252.77 & 0.91 & 236.60 & 1.16 & 4.06 & \\
\hline 16 & Belgium & 0.99 & 264.85 & 0.90 & 237.58 & 1.17 & 4.08 & \\
\hline 17 & Brazil & 1.02 & 262.05 & 0.79 & 240.66 & 1.18 & 4.13 & $\begin{array}{l}\text { For restricted use as } \\
\text { a decorative material }\end{array}$ \\
\hline 18 & European Union (Data Base) & 1.05 & 285.84 & 0.98 & 253.58 & 1.24 & 4.36 & \\
\hline 19 & Italy & 1.07 & 286.77 & 0.95 & 255.46 & 1.25 & 4.39 & \\
\hline 20 & Brazil & 1.12 & 297.97 & 0.93 & 263.60 & 1.29 & 4.53 & \\
\hline 21 & Egypt/Gable El Majal & 1.04 & 293.24 & 1.33 & 269.64 & 1.32 & 4.63 & \\
\hline 22 & Turkey & 1.12 & 304.87 & 1.06 & 269.86 & 1.32 & 4.64 & \\
\hline 23 & Pakistan (S. S. Garhi Granite) & 1.14 & 293.54 & 0.93 & 272.16 & 1.34 & 4.68 & \\
\hline 24 & China & 1.29 & 348.55 & 1.18 & 307.96 & 1.51 & 5.29 & \\
\hline 25 & Cypress & 1.31 & 356.77 & 1.16 & 308.16 & 1.51 & 5.29 & \\
\hline 26 & Malaysia & 1.30 & 355.81 & 1.19 & 308.04 & 1.51 & 5.29 & \\
\hline 27 & Spain & 1.31 & 354.87 & 1.18 & 312.02 & 1.53 & 5.36 & \\
\hline 28 & Iran & 1.28 & 347.57 & 1.29 & 313.86 & 1.54 & 5.39 & \\
\hline 29 & Turkey/Sivrihisar & 1.34 & 366.96 & 1.17 & 314.58 & 1.54 & 5.40 & \\
\hline 30 & Sweden & 1.32 & 358.45 & 1.26 & 317.52 & 1.56 & 5.45 & \\
\hline 31 & Yemen & 1.40 & 369.51 & 1.14 & 328.82 & 1.61 & 5.65 & \\
\hline 32 & Portugal & 1.41 & 381.62 & 1.35 & 342.34 & 1.68 & 5.88 & \\
\hline 33 & South Africa & 1.46 & 399.11 & 1.33 & 345.02 & 1.69 & 5.93 & \\
\hline 34 & China & 1.53 & 417.33 & 1.38 & 361.68 & 1.78 & 6.21 & \\
\hline 35 & Finland & 1.54 & 420.93 & 1.39 & 363.62 & 1.78 & 6.25 & \\
\hline 36 & Brazil & 1.55 & 421.77 & 1.36 & 364.00 & 1.79 & 6.25 & \\
\hline 37 & India & 1.62 & 447.95 & 1.53 & 385.24 & 1.89 & 6.62 & \\
\hline 38 & Brazil & 1.67 & 448.07 & 1.46 & 396.44 & 1.95 & 6.81 & \\
\hline 39 & Austria & 1.85 & 504.51 & 1.47 & 422.30 & 2.07 & 7.25 & \\
\hline 40 & Egypt/HomertWaggat South & 1.87 & 495.43 & 1.57 & 442.32 & 2.17 & 7.60 & $\begin{array}{l}\text { Not to be used } \\
\text { for any purpose }\end{array}$ \\
\hline 41 & Turkey (Ezine) & 2.00 & 558.01 & 1.98 & 480.26 & 2.36 & 8.25 & \\
\hline 42 & Egypt Wadi Karim & 2.07 & 506.14 & 1.52 & 498.84 & 2.45 & 8.57 & \\
\hline 43 & India & 2.20 & 612.76 & 1.91 & 508.08 & 2.49 & 8.73 & \\
\hline 44 & Turkey/Kaymaz & 2.68 & 757.67 & 2.87 & 655.60 & 3.22 & 11.26 & \\
\hline 45 & Egypt/HomertWaggat North & 2.71 & 767.02 & 3.39 & 696.98 & 3.42 & 11.97 & \\
\hline 46 & Italy & 3.50 & 980.46 & 3.09 & 811.24 & 3.98 & 13.94 & \\
\hline 47 & Egypt/Gable Ell Misikat-1 & 4.38 & 1295.37 & 6.70 & 1189.68 & 5.84 & 20.44 & \\
\hline 48 & Egypt/Um Taghir & 4.96 & 1372.24 & 5.22 & 1221.70 & 6.00 & 20.99 & \\
\hline 49 & Pakistan (Ambela Granite) & 5.59 & 1605.82 & 6.12 & 1360.32 & 6.68 & 23.37 & \\
\hline \multirow[t]{3}{*}{50} & Egypt Gable Gattar II & 21.01 & 6267.12 & 33.20 & 5752.06 & 38.23 & 98.81 & \\
\hline & Worldwide granite average & 1.17 & 317.66 & 1.08 & 279.64 & 1.37 & 4.8 & \\
\hline & Limit values & $<1$ & 370 & $<1$ & 84 & 2 & - & \\
\hline
\end{tabular}

Worldwide granite averages are from Table 6. Limit values were taken from EC, 1999 ( $I \gamma)$; Beretka and Mathew, $1985 R a_{e q}$ and $H_{i n}$ ); UNSCEAR, $2000\left(E_{i n}\right)$ and Nordic, $2000\left(I_{a}\right)$. 
Appendix. Formulae used for the calculation of the radiation indices of Nagarparkar granite, Pakistan, and their limit values.

\begin{tabular}{lccc}
\hline Hazard Index & Formula & Limit & Reference \\
\hline 1. Gamma Index & $I_{\gamma}=\frac{A_{R a}}{300}+\frac{A_{T h}}{200}+\frac{A_{K}}{3000}$ & $<1$ & EC (1999) \\
2. Radium equivalent activity $\left({\left.\mathrm{Bq} . \mathrm{kg}^{-1}\right)}\right.$ & $R a_{e q}=\left(\frac{A_{R a}}{370}+\frac{A_{T h}}{259}+\frac{A_{K}}{4810}\right) \times 370$ & 370 & Beretka and Mathew (1985) \\
3. Internal hazard index & $H_{i n}=\frac{A_{R a}}{185}+\frac{A_{T h}}{259}+\frac{A_{K}}{4810}$ & $<1$ & Ibrahim (1999) \\
4. Indoor external dose $\left(\mathrm{nGy} \cdot \mathrm{h}^{-1}\right)$ & $\dot{D}_{i n}=0.92 A_{R a}+1.1 A_{T h}+0.08 A_{K}$ & 84 (world Average) & EC (1999) \\
5. Annual effective indoor dose $\left(\mathrm{mSv} \cdot \mathrm{y}^{-1}\right)$ & $E_{i n}=4.905 \times 10^{-3} D_{i n}$ & 2.00 & Ali et al. (2011) \\
6. Excess Lifetime Cancer Risk & $E L C R=\left(E_{i n}\right) \times L E \times R F$ & $0.29 \times 10^{-3}$ & Taskin et al. (2009) \\
\hline
\end{tabular}

\section{Conclusion}

The hazard indices $\left(I \gamma, R a_{e q}, H_{\text {in }}\right.$ and $\left.D_{\text {in }}\right)$ of Nagarparkar granite are lower than the worldwide granite averages and their limit values. The $E_{\text {in }}$ is lower than the worldwide granite average and its limit value. The $E L C R_{\text {in }}\left(2.4 \times 10^{-3}\right)$ is lower than the worldwide granite average $\left(4.8 \times 10^{-3}\right)$ but slightly higher than the indoor limit value $\left(1.16 \times 10^{-3}\right)$. So, the radioactivity associated with Nagarparkar granite has negligible chances of inducing cancer in the inhabitants of buildings.

Among the world's granites, Nagarparkar granite is the 7th safest granite, with low radioactivity. It can be used as a basic construction and decorative material without any restriction.

The current limit values of various radiation indices do not seem appropriate for screening granites for various uses such as the categories: basic construction stone, for restricted use or not to be used for any type of construction. Granites from 50 locations were categorized for various uses.

The four granites of Pakistan show that the radioactivity increases from south to north in a systematic manner. The highest radioactivity is associated with the granites located in the Eurasian-Indian Plate collision zone in the Himalayan ranges of Pakistan in the north.

\section{References}

Abd El-Mageed A.I., El-Kamel A.H., Abbady A., Harb S., Youssef A.M.M., Saleh I.I. (2011) Assessment of natural and anthropogenic radioactivity levels in rocks and soils in the environments of Juban town in Yemen, Radiat. Phys. Chem. 80, 710-715.

Akhtar N., Tufail M., Ashraf M., Iqbal M.M. (2005) Measurement of environmental radioactivity for estimation of radiation exposure from saline soil of Lahore, Pakistan, Radiat. Meas. 39, 11-14.

Alharbi W.R., Al Zahrani J.H. (2012) Assessment of natural radioactivity levels and associated radiation hazards of building materials used in Saudi Arabia, J. Am. Sci. 8, 10.

Ali M., Qureshi A.A., Waheed A., Baloch M.A., Qayyum H., Tufail M., Khan H.A. (2011) Assessment of radiological hazard of NORM in Margalla Hills limestone, Pakistan, Environ. Monit. Assess. 184, 4623-4634.

Ali M., Shariff A.A., Qamar N., Laghari A. (2012) Comparison of the Nagarparkar (Pakistan) and Malani (India) granites with reference to uranium and thorium abundances, Journal of Himalayan Earth Sciences 45 (1), 67-76.
Amanat A., Orfi S.D., Qureshi A.A. (2002) Assessment of the Natural Radioactivity and its radiological hazards in Shewa Shahbaz Garhi Igneous Complex, Peshawer Plain, N.W. Pakistan, Health Phys. 82 (1), 74-79.

Anjos R.M., Veiga R., Soares T., Santos A.M.A., Aguiar J.G., Frascá M.H.B.O., Brage J.A.P., Uzêda D., Mangia L., Facure A., Mosquera B., Carvalho C., Gomes P.R.S. (2005) Natural radionuclide distribution in Brazilian commercial granites, Radiat. Meas. 39, 245-253.

Anjos R.M., Ayub J., Cid A.S., Cardoso R., Lacerda T. (2011) External gamma-ray dose rate and radon concentration in indoor environments covered with Brazilian granites, J. Environ. Radioact. 102 (11), 1055-1061.

Arafa W. (2004) Specific activity and hazards of granite samples collected from the eastern desert of Egypt, J. Environ. Radioact. 75, 315-327.

Asghar M., Tufail M., Javed S., Abid A., Waqas M. (2008) Radiological implications of granite of Pakistan, J. Radiol. Prot. 28, 387-399.

Benke R.R., Kearfott K.J. (1999) Soil sample moisture content as a function of time during oven drying for gamma ray spectroscopic measurements, Nucl. Instrum. Methods Phys. Res. A 422, 817819.

Beretka J., Matthew P.J. (1985) Natural radioactivity of Australian building materials, industrial wastes and by-products, Health Phys. 48, 87-95.

Chen C.J., Lin Y.M. (1996) Assessment of building materials for compliance with regulations of ROC, Environ. Int. 22, 221-226.

El-Arabi A.M. (2007) ${ }^{226} \mathrm{Ra},{ }^{232} \mathrm{Th}$ and ${ }^{40} \mathrm{~K}$ concentrations in igneous rocks from eastern desert, Egypt and its radiological implications, Radiat. Meas. 42, 94-100.

El-Shershaby A. (2002) Study of radioactivity levels in granite of Gable-Gattar II in the north eastern desert of Egypt, Appl. Radiat. Isotopes 57, 131-135.

EC (1999) European Commission, Radiation Protection 112: Radiological Protection Principles Concerning the Natural Radioactivity of Building Materials.

Faure G. (1986) Principles of Isotope Geology, 2nd edn. Wiley, New York.

Guillén J., Tejado J.J., Baeza A., Corbacho J.A., Muñoz J.G. (2014) Assessment of radiological hazard of commercial granites from Extremadura (Spain), J. Environ. Radioact. 132, 81-88.

Ibrahim N. (1999) Natural activities of ${ }^{238} \mathrm{U},{ }^{232} \mathrm{Th}$ and ${ }^{40} \mathrm{~K}$ in Building Materials, J. Environ. Radioact. 43, 255-258.

ICRP Publication 65 (1994) International Commission on radiation protection against Radon-222 at home and at work., Ann. ICRP 23 (2). 
Jahangiri A., Ashrafi S. (2011) Natural radioactivity of granites used as building materials in Iran, J. Environ. Stud. 36, 4.

Kazmi A., Khan R.A. (1973) The report on the geology, mineralogy and mineral resources of Nagarparkar, Pakistan. Geol. Surv. Pakistan, Information release 64, 44-56.

Khaleel M.T. (2013) Measurement of natural radioactivity and radon exhalation rate in granite samples used in Palestinian buildings, Arab J. Sci. Eng. 38, 201-207.

Khan K., Khan H., Tufail M., Khatibeh A.H., Ahmad N. (1998) Radiometric analysis of Hazara phosphate rocks and fertilizers in Pakistan, Egypt. J. Environ. Radioact. 38, 77-384.

Kitto M.E., Haines D.K., Menia T.A. (2009) Assessment of gammaray emissions from natural and manmade decorative stones, $J$. Radioanal. Nucl. Chem. 282, 409-413.

Knoll G.F. (2000) Radiation Detection and Measurement, 3rd edn. Wiley, New York.

Krieger R. (1981) Radioactivity of construction materials, BetonwerkFertigtiel Tech. 47, 468.

Krisiuk E.M., Tarasov S.I., Shamov V.P., Shalak N.I., Lisa Chenko E.P., Gomelsky L.G. (1971) A study on building materials. Research Institute of Radiation Hygiene, Leningrad.

Krstić D., Nikezić D., Stevanović N., Vucié D. (2007) Radioactivity of some domestic and imported building materials from South Eastern Europe, Radiat. Meas. 42, 1731-1736.

Le S.C., Kein C.K., Lee D.M., Kang H.D. (2001) Natural radionuclides content and radon exhalation rates in building material used in South Korea, Radiat. Prot. Dosim. 94, 269-274.

Mao Y., Liu Y., Fu Y., Liu L. (2006) Physical models and limits of radionuclides for decorative building materials, Health Phys. 90 (5), 471-476.

Menager M.T., Heath M.J., Ivanovich M., Montjotin C., Barillon C.R., Camp J., Hasler S.E. (1993) Migration of uranium from uranium-mineralized fractures into rock matrix in granite: implications for radionuclide transport around a radioactive waste repository, Radiochim. Acta 66/67, 47-83.

National Cancer Institute, USA (2009) Surveillance, Epidemiology, and End Results (SEER) Program. The Surveillance, Epidemiology, and End Results (SEER) Program of the National Cancer Institute works to provide information on cancer statistics in an effort to reduce the burden of cancer among the U.S. population.

Nordic (2000) Naturally Occurring Radiation in the Nordic Countries: Recommendations. The Flag-Book Series; The Radiation Protection Authorities in Denmark, Finland, Iceland, Norway and Sweden, Reykjavik.

Orgun Y., Altinsoy N., Gultekin A.H., Karahan G., Celebi N. (2005) Natural radioactivity levels in granitic plutons and ground waters in Southeast part of Eskisehir, Turkey, Appl. Radiat. Isotopes $\mathbf{6 3}$, 267-275.

Otoo F., Adukpo O.K., Darko E.O., Emi-Reynolds G., Awudu A.R., Ahiamadjie H., Tandoh J.B., Hasford F., Adu S., Gyampo O. (2011) Assessment of natural radioactive materials in building materials used along the coast of Central Region of Ghana, Res. J. Environ. Earth Sci. 3 (3), 261-268.
Pathan M.T., Rais A. (1975) Preliminary report of the investigation of Nagarparkar igneous complex, Sindh University Journal of Science 1, 93-97.

Pavlidou S., Koroneos A., Papastefanou C., Christofides G., Stoulos S., Vavelides M. (2006) Natural radioactivity of granites used as building materials, J. Environ. Radioact. 89, 48-60.

Quindos L.S., Fernandez P.L., Soto J. (1987) Building Materials as Source of Exposure in Houses, Vol. 2, p. 365. Institute for Water, Soil and Air Hygiene, Berlin.

Qureshi A.A., Jadoon I.K., Wajid A.A., Attique A., Anees. M., Manzoor S., Waheed A., Masood A., Tubassam A. (2014) Study of Natural Radioactivity in Mansehra Granite, Pakistan: Environmental Concerns, Radiat. Prot. Dosim. 159 (4), 466-475.

Qureshi A.A., Sultan A., Rashid A., Ali M., Waheed A., Manzoor S., Baloch M.A., Matiullah, Batool, S., Khan H.A. (2012) Geological and radiological studies of the Mount Arafat, Mekkah, Saudi Arabia, J. Radioanal. Nucl. Chem. 293, 955-963.

Sannappa J., Ningappa C., Prakash K.N. (2010) Natural radioactivity levels in granite regions of Karnataka State, Indian J. Pure Appl. Phys. 48, 817-819.

Stoulos S., Manolopoulou M., Papastefanou C. (2003) Assessment of natural radiation exposure and radon exhalation from building materials in Greece, J. Environ. Radioact. 69, 225-240.

Taskin H., Karavus M., Topuzoglu P., Ay A., Hindiroglu S., Karahan G. (2009) Radionuclide concentrations in soil and lifetime cancer risk due to the gamma radioactivity in Kirklareli, Turkey, $J$. Environ. Radioact. 100, 49-53.

Trevisi R., Risica S., Alessandro M.D., Paradiso D., Nuccetelli C. (2012) Natural radioactivity in building materials in the European Union: a database and an estimate of radiological significance, $J$. Environ. Radioact. 105, 11-20.

Tufail M., Akhtar N., Waqas M. (2006) Measurement of terrestrial radiation for assessment of gamma dose from cultivated and barren soils of Faisalabad in Pakistan, Radiat. Meas. 41, 443-451.

Tufail M., Akhtar N., Sabiha-Javied, Hamid T. (2007) Natural radioactivity hazards of building bricks fabricated from saline soil of two districts of Pakistan, J. Radiol. Prot. 27, 481-492.

Turhan (2012) Estimation of possible radiological hazards from natural radioactivity in commercially-utilized ornamental and countertops granite tiles, Annals of Nuclear Energy 44, 34-39.

Tzortzis M., Tsertos H., Christofides S., Christodoulides G. (2003) Gamma radiation measurements and dose rates in commercially used natural tiling rocks (granites), J. Environ. Radioact. 70, 223235.

UNSCEAR (2000) United Nations Scientific Committee on the Effects of Atomic Radiation Sources and effects of ionizing radiation, Report to United Nations, New York.

Wynne A.B. (1867) Memoirs on the Geology of Kutch, Geological Survey of India, Memoir.9:293.

Xinwei L., Linquing W., Xiadon J. (2006) Radiometric analysis of Chinese commercial granites, J. Radioanal. Nucl. Chem. 267, 669-673.

Xinwei et al. (2008). Radiat. Prot. Dosim. 128, 471-476.

Yang Y.X., Wu X.M., Jiang Z.-Y. (2005) Radioactivity concentrations in soils of the Xiazhuang granite area, China, Appl. Radiat. Isotopes 63, 255-259. 